\title{
Demographic Characteristics of Patients Admitted to Private Hospital Emergency Service
}

\section{Özel Hastane Acil Servisine Başvuran Hastaların Demografik Özellikleri}

\author{
DMurat Koyuncu', Murat Yıldar2, \\ 'Özel Bahat Hospital, Emergency Department, Istanbul, Turkey \\ ${ }^{2}$ Özel Bahat Hospital, Department of General Surgery, İstanbul, Turkey
}

\begin{abstract}
Aim: Increasing the productivity of emergency services is only possible with the documentation and analysis of data on services provided. In this study, we aimed to evaluate demographic characteristics of patients admitted to the emergency unit using a computer-based patient registry system.
\end{abstract}

Material and Method: 33,886 outpatients admitted to the emergency unit between 01.09.2017 and 31.08.2019 were retrospectively analyzed. Demographic characteristics of the patients, main complaints, time of admission, triage classification, and International Classification of Diseases diagnosis codes were evaluated.

Results: Among outpatients admitted to the emergency unit, $58 \%$ were males and $42 \%$ were females. A total of $43 \%$ outpatients were $0-12$ months of age, $21 \%$ were $1-5$ years of age, $15 \%$ were 28-39 years of age, and 9\% were $40-64$ years of age. In total, 39\% outpatients were admitted to the emergency unit due to upper respiratory tract diseases. Of the patients, $95,42 \%$ were treated in the outpatient setting. The highest admission rates were in December and January. The highest admission rate was on Sunday, while the least was on Wednesday and Thursday. The highest admission time period was between 20:00-00:00, while the least was between 04:00-08:00.

Conclusion: Our study results show that supportive measures for healthcare professionals including specialists and medical equipment should be provided, in particular between 20:0000:00, at the weekends, and in winter seasons, when the overall admission rate increases. Based on these results, we suggest that documentation and analysis of demographic data of patients admitted to the emergency unit can contribute to physical and labor force planning of emergency units.

Keywords: Emergency, triage, private hospital

\section{Öz}

Amaç: Acil servis hizmetlerinin daha verimli hale getirilebilmesi ancak verilen hizmete ait verilerin dokümantasyonu ve değerlendirilmesi ile mümkün olabilir. Bu çalışmada bilgisayar tabanlı hasta veri kayıt sistemi kullanılarak acil servise başvuran hastalar demografik açıdan değerlendirildi.

Gereç ve Yöntem: 01.09.2017 ila 31.08.2019 tarihleri arasında acil servise ayaktan başvuran 33.886 hasta retrospektif olarak değerlendirildi. Hastaların demografik özellikleri, şikâyetleri, başvuru saati, tiraj sınıflaması ICD tanı kodlama sistemine göre tanıları değerlendirildi.

Bulgular: Acile başvuran hastaların \%58 erkek, \%42 kadın idi. Hastalarımızın \%43'ü 0-12 ay yaş gurubunda, \%21'i 1-5 yaş grubunda, $\% 15$ 'i hasta 18-39 yaş grubunda, ve \%9'u 40-64 yaş grubunda idi. Hastaların \%39'u hasta üst solunum yolu hastalıkları nedeniyle başvurmuştu. Hastaların \%95.42'si ayaktan tedavisi yapılmıştır. En fazla başvuru Aralık (\%12) ve Ocak (\%11) aylarında yapılmıştı. Hastaların en çok başvuru yaptı̆ı̆ gün pazar (\%25), en az ise çarşamba ve perşembe (\%10) idi. En çok başvuru yapılan saat 20-00 (\%30) en az ise 04-08 (\%7) idi.

Sonuç: Hasta yoğunluğunu fazla olduğu kış aylarında, hafta sonu ve 20 ila 24 saatleri arasında hekim, sağık personeli ve araç-gereç takviyesi gerektiği görülmektedir. Acil servise başvuran hastaların demografik verilerinin kaydı ve analizi, acil servislerin fiziki ve işgücü planlaması açısından katkıda bulunabilir.

Anahtar kelimeler: Acil servis, triyaj, özel hastane 


\section{INTRODUCTION}

Emergency services are the healthcare units that have to make a rapid and at the same time correct diagnosis due to the organ or life risk of the patient group they serve and provide this service 24 hours a day, seven days a week. Therefore, due to many sociological reasons such as fast and minimum waiting time in emergency services, not requesting co-payments from patients, rapid turnover of examination results, application of non-emergency patients with simple ailments to receive services, the emergency services become crowded.

Overcrowding of the emergency service causes personel and equipment shortages, and this vicious circle leads to patient and employee dissatisfaction. Bringing the emergency department staff and equipment to the most appropriate number and quality will contribute to the satisfaction of the patient/patient relatives and employees. For this reason, both the physical conditions of the emergency services and the competence and number of staff should be at an optimal state. The most ideal number and quality of required emergency service personnel, equipment are tried to be provided by both examining the emergency service applications, and retrospectively investigating the patients.

In this way, the extent which the increase in the number of patients due to seasonally increasing diseases is reflected in the emergency service is determined. It can also contribute to the organization of polyclinics of hospitals. ${ }^{[1-3]}$

In our country, healthcare service and emergency healthcare, which has an important place in this service, are provided by public hospitals, while a significant portion of this service by private hospitals established by private enterprises. Private hospitals are owned by real or legal persons and provide examination, medical intervention, surgery, medical care and necessary treatments for inpatients or outpatients. ${ }^{[4]}$

In this study, it was aimed to contribute to the data of our country by determining the demographic and epidemiological characteristics of the patients who applied to the emergency service of a private hospital in Istanbul.

\section{MATERIAL AND METHOD}

Necessary permissions were obtained from the hospital administration for this study. The study was a retrospective and file-scanning study and ethics committee approval vas taken from the Clinical Research Ethic Committee of Sultangazi Haseki Research and Education Hospital. The file numbers of the patients who applied to the private hospital emergency service during 24 months between 09.01.2017 and 08.31.2019 were retrieved from the hospital patient information system. Again, the file numbers and patient records were analyzed retrospectively from the hospital information system. Patients whose medical chartscould not be reached and those with missinginformation were excluded from the study. A total of 33,886 patients were included in the study. The demographic characteristics of the patients included in the study were evaluated in terms of the time of their admission, triage classification and diagnoses they received. Admissiontimes were grouped according tothe month (January, February, March, April, May, June, July, August, September, October, November, December), day (Monday, Tuesday, Wednesday, Thursday, Friday, Saturday, Sunday) andhourly shifts in the time periods of the day. (00:00-03:59, 04:00-07:59, 08:00-11:59, 12:00-15:59, 16:00-19:59, 20:0023:59). Triage classification was made according to Annex-7 mentioned in the section 'Color Coding and Triage Application' in Article 8 of the 'Communiqué on the Application Procedures and Principles of Emergency ServicesProvided inInpatient Health Care Facilities' published by the Ministry of Health in the Official Gazette with the number 27378 on October 16, 2019. ${ }^{\text {[5] }}$

Statistical Analysis:Results of the data analyzedwere evaluated using Microsoft Excel XP and SPSS (version 13.0, SPSS Inc., Chicago, Illinois, USA) programs. Values are given as numbers and percentages.

\section{RESULTS}

A total of34,126 patients applied to the private hospital where the study was conducted for two years. Two hundred and fortypatients were excluded from the study, and 33.886 patients were included in the study.

During this period 19,464 (58\%) male, and 14,422 (42\%) female patients applied to the hospitalAverageages of the male, and female patients were 13.86, and14.95, years respectively. While43\% (14.644) of the patients referred to our hospitals were infants (Table 1).

\begin{tabular}{lcccccc} 
Table 1. Distribution of the patients admitted according to age and gender \\
\cline { 2 - 7 } Age Groups & $\mathbf{n}$ & Male & \multicolumn{2}{c}{ Female } & \multicolumn{3}{c}{ Total } \\
\cline { 2 - 7 } & 8.514 & 25 & 6.130 & 18 & 14.644 & 43 \\
\hline Infancy (0-12 months) & 4.153 & 12 & 3.147 & 9 & 7.300 & 21 \\
Preschool (1-5 years) & 1.342 & 4 & 949 & 3 & 2.291 & 7 \\
School Age (6-11 years) & 489 & 1 & 348 & 1 & 837 & 2 \\
Adolescence (12-17 years) & 3.131 & 9 & 2.175 & 6 & 5.306 & 15 \\
Youth (18-39 years) & 1.532 & 5 & 1.224 & 4 & 2.756 & 9 \\
Middle Age (40-64 years) & 752 & 2 & 303 & 1 & 449 & 3 \\
Aged ( $\geq 65$ years) & 19.464 & 58 & 14.422 & 42 & 33.886 & 100 \\
Total & & & & & & \\
\hline
\end{tabular}

When the types of social security that the patients had were examined, it was seen that 59\% (19.786) of them were under the coverage ofSSI (Social Security Institution: SSK) and the majority ofthe SSI members were male. Only $8 \%(n=2.921)$ of the refugees who came to our country after fleeing the civil war in Syria had "Temporary Protection" social security. However, 'General Health Insurance'was provided to only 3\% ofthe poor citizens of Republic of Turkey who had not any income (Table 2). 
Table 2. Distribution of the patients according to types of social security coverage

\begin{tabular}{lcccccc}
\multirow{2}{*}{ Social Security } & \multicolumn{2}{c}{ Male } & \multicolumn{2}{c}{ Female } & \multicolumn{2}{c}{ Total } \\
\cline { 2 - 7 } & $\mathbf{n}$ & $\%$ & $\mathbf{n}$ & $\%$ & $\mathbf{n}$ & $\%$ \\
\hline SSI $^{1}$ & 12.087 & 36 & 7.699 & 23 & 19.786 & 59 \\
BAĞKUR $^{2}$ & 2.214 & 7 & 1.736 & 5 & 3.950 & 12 \\
Retirement Fund & 1.712 & 5 & 2.140 & 6 & 3.852 & 11 \\
Temporary Protection & 1.785 & 5 & 1.136 & 3 & 2.921 & 8 \\
Insurance & 672 & 2 & 624 & 2 & 1.296 & 4 \\
International Insurance & 545 & 2 & 501 & 1 & 1.046 & 3 \\
Private Insurance & 449 & 1 & 586 & 2 & 1.035 & 3 \\
General Health Insurance & 19.464 & 58 & 14.422 & 42 & 33.886 & 100 \\
\hline Total & \multicolumn{7}{c}{ ISI: Social Insurance Institution } \\
2BAGKKUR: Social security organization for artisans and the self-employed \\
\hline
\end{tabular}

When we examine the patients according to triage coding and diseases, it is seen more than half of the patients (56\%) who applied received the Green Triage Code. It has been determined that thevastmajority (13.070) of thepatientswhoreceivedGreen Triage Code hadupper respiratory tract infections (Table 3 ). It was observed that $95.42 \%$ of the patients were discharged after being examined and treated in the emergency service When we examine the patients who applied to the Private Hospital Emergency Department according to the month of their applications; the patients mostly applied in December (12\%) followed by January (11\%) and August (11\%). The least number of applications were seenin July, with a rate of 6 percent (Figure 1). The patientsmostly applied on Sunday (25\%) followed by Saturday (19\%). It was determined that the least number of applications occurredin the middle of the week (Wednesday and Thursday with 10\% each) (Figure 2). When the application time is evaluated, it is seen that the highest number of applications (30\%) were made during the nightshift between 8:00 PM and midnight which is called the"prime-time". It was determined that the least number of applications (7\%) were madefrom 04:00 am to the start of the working hours (Figure 3).

DISTRIBUTION OF THE PATIENTS' ADMISSIONS ACCORDING TO MONTHS OF THE YEAR

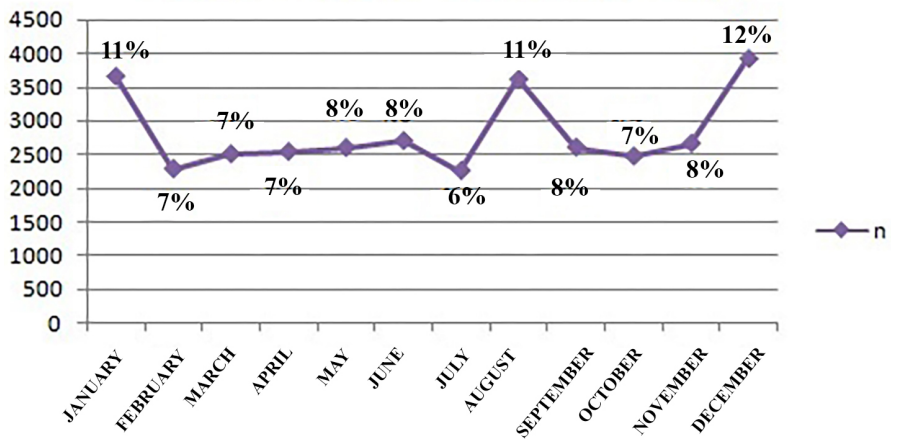

Figure 1. Distribution of the patients' admissions according to months of the year.
Table 3. Number of patients according to triage codes, anddisease groups.

Male Female Total

\section{Red Triage Code}

Allergy, Angioneurotic Edema

Cardiopulmonary Arrest

Pulmonary Infection

Surgical Abdominal Pain

Extremity Embolism

Gastrointestinal Bleeding

Intoxication

Bleeding Diathesis

Heart Diseases

COPD*, Bronchial Asthma

Seizures

Pulmonary Embolism

Central Nervous System Infections

Sepsis

Cerebrovascular Diseases

Trauma

Burns

Total Number of Patients with Red

Triage Code

\section{Yellow Triage Code}

2

246

Urinary Infection
Allergy

Pulmonary Infection

Renal Failure, Electrolyte Disorder

Electrocution

Epistaxis

Facial Paralysis

Gastrointestinal Infection

Animal, Insect Bites

Hypo/Hyperglycemia

Heart Diseases

COPD*, Bronchial Asthma

Non-Surgical Abdominal Pain

Psychiatric Emergencies

Trauma

Urologic Emergencies

Vertigo

Foreign Body in Body Cavities

306

Burns

Total Number of Patients with Yellow Triage Code

\section{Green Triage Code}

Non-Specific Headache

Skin-Soft Tissue Infection

Dermatitis

Gastrointestinal Infection

$217 \quad 297 \quad 514$

84

136

1.354

Non-Traumatic Musculoskeletal Pain

Conjunctivitis

Upper Respiratory Tract Infections

Trauma

7.298

1.376

85

Burns

Total Number of Patients with Green

Code

11.046

(\%33)

19.464

(\%58)

\section{4}




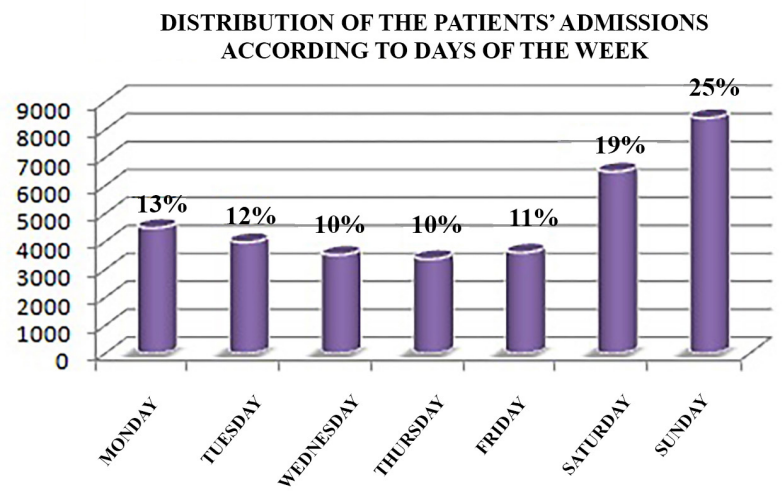

Figure 2. Distribution of the patients' admissions according to days of the week

DISTRIBUTION OF THE PATIENTS' ACCORDING TO THEIR ADMISSION TIME

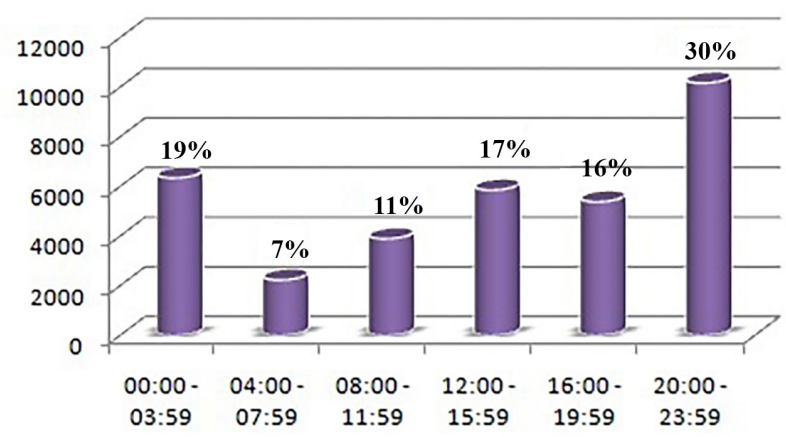

Figure 3. Distribution of the patients according to their admission times

\section{DISCUSSION}

Emergency Services are hospital departments that have toadmit everypatient that applied, have to make a fast and correct decision, can be accessibleevery day and every hour of the week, and has a wide range of patients. ${ }^{[2]}$ It has the characteristic of being the showcase of a hospital, as it is frequently said by the administrators, which mostlyencounterpeopledue to the long working time and highernumber of patient applications, and demonstratesthe hospital's service quality and competence, examination and treatment efficiency.

However, emergency rooms (ERs)becomecrowded due tothe increasing number of admissions to ERs in our country which naturally result indissatisfaction of patients and staff. ${ }^{[6]}$ Emergency room patients rightly expect quality and priority health care service. ${ }^{[1,2]}$ Providing fast and accurate service at high quality can be achieved with a good planning of staff and equipment.

Descriptive studies on the demographic characteristics and diagnostic and treatment process of patients admitted to emergency services in our country are mostly carried out in tertiary healthcare institutions. In this study, the patients who applied to a private hospital emergency service, which has been serving for 25 years and operating in the central district namely in the suburbs of our metropolitan citywhere the people with middle and lower socio-economic class live and work, were evaluated in terms of demographic characteristics, admission time and triage codes. This study is the first study conducted in our countryusing a private hospital'semergency service data.

In the study conducted by Çevik et al. ${ }^{[7]}$ in a state hospital, it was determined that $50.86 \%$ of the patients admittedto the emergency serviceswere women and $49.14 \%$ of them were men. The majority of the admissions (37.89\%) consisted of young adults (20-39 years old), and the authorsstated that greaternumber of these patients aged 20-24 and over 65 yearscompared to other age groups. In the study conducted by Kılıçarslan et al. ${ }^{[8]}$ at auniversity hospital, the investigators determined that $52.6 \%$ of the patients were male and the majority of the patients (37.89\%) were young adults (20-39 years old). Besides, among them more frequentlypatientsaged 20-24 and over 65 years of age were more numerousthan the other age groups.

In the study conducted by Edirne et al. ${ }^{[19]}$ in a university hospital, the authors stated that $43.2 \%$ of the patients were male. In the study conducted by Köse et al. ${ }^{[3]}$ in a state hospital, the investigatorsfound that $54.8 \%$ of applications were made bymale patients, andthe most (77\%) of themaged $17-65$ years. While Türkdoğan et al. ${ }^{[10]}$ determined that most frequently (55.2\%) female patients hadappliedto the emergency services. Aydın et al. ${ }^{[2]}$ observed that the ER applications were more frequently $(51.53 \%)$ made by male patients In the study conducted by Polat et al. ${ }^{[1]]}$ the authors stated that $25 \%$ of emergency room admissions in our country consisted of patients in the pediatric age group.

In this study, when the patients who applied to the emergency service were evaluated according to their gender, admissions consisted of $58 \%$ male and $42 \%$ female patientswithout anysignificant difference between both genders ( $p>0.05$ ) (Table 1). When the patients are examined in terms of age periods, it is seen that the least admission is in infancy with $43 \%$. The least number of applicants are adolescents followed by the elderly patient group. As can be seen in the literature, admissions to the emergency department in terms of age and gender vary according to the region where the hospital is located.

Overyears, improvements and reforms have been made in the fields ofhealth and social security in Turkey. The patients who did not have social security coverage and income were provided with social security firstly under the name of 'Green Card' and then the scope of the social security coveragewas expanded under the 'General Health Insurance!.[12] Health insurance has been provided for asylum seekers who came to our country after fleeing from the civil war in Syria, and the "Directive on Principles Regarding Health Services to be Provided to Temporary Protection" was published by the Ministry of Health in 2015. With this directive, a social security umbrella called "Temporary Protection" was created for refugees ${ }^{[13]}$ 
In the study conducted by Çevik et al. ${ }^{[7]}$ in a state hospital, the patients who applied to the emergency services were examined according to their types of social security coverage they received and found that the respective percentages of patients had benefited from the Retirement Fund (42.6\%), SSK (38.59\%), Bağ-Kur (12.28\%), Green Card (1.65\%), while $3.12 \%$ of the patients were not under any social security coverage. In the study conducted by Köse et al. ${ }^{[3]}$ in a state hospital, $64.4 \%$ of the patients who applied to the emergency serviceswere green card holders, and the otherpatients were affiliated to the Social Insurancelnstitution (SSK) $(20.5 \%)$,to the Social Security Institution (SGK) (4.5\%), Bağ-Kur (4.4\%), to the Retirement Fund (2.1\%), and others 3.6\%.

In the study conducted by Tanrıkulu et al. ${ }^{[1]}$ in a training and research hospital, the authors stated that most (56.2\%) of their patients were affiliated to SSK followed by green card holders (25.6\%). While 1\% patients paid their health expensesby themselves. The patients whose social securitycoverage is defined as "forensic" due to forensic cases such as traffic accidents, assaults, injuries and whose health insurance cannot be determined exactly constituted $3 \%$ of the admissions.

In our study most of the patients (59\%: $n=19.786)$ were members of SII (SSK)and the majority of the SII members were male. Only $8 \%(n=2.921)$ of thepatients had "Temporary Protection" social security, which covers refugees who came to our country after fleeing the civil war in Syria. However, only $3 \%$ of the patients who were the citizens of the Republic of Turkey and without any income were provided with 'General Health Insurance' (Table 2).

When the literature and our study are examined, it is seen that the rates of social security types differ according to the type of health care institute such asuniversity, educationandresearch hospital, state and private hospital, as well as the socio-economic level of the region where the patient is living.

Although the increasing number of admissionsto emergency services is a worldwide problem, this problem has almost reached the level of disaster in our country. Due to the fact that emergency services are free of charge, examinations are performedrapidly without waiting, admission of non-urgent cases to the emergency services, the growing volume of patients cannot be intervened in time, which results in dissatisfaction with physicians and patients/relatives and consequently violence against health care professionals. In this case, the method to distinguish between emergency and non-emergency patients and how to determine the priority of patients for treatment becomes important. Triage scales are used to distinguish between emergency and non-emergency patients. Using triage methods, the waiting period ofthe patient without treatment is determined, and if the condition of the patient is very urgent, he/sheis immediately intervened, and the patient's loss of life is prevented.
In our country, the 'Communiqué on the Application Procedures and Principles of Emergency Service Services in Inpatient Health Facilities' published in the Official Gazette with the number 27378 on October 16, 2019, published by the Ministry of Health, is included in the Annex-7 mentioned in the 'Color Coding and Triage Application' section in Article 8. Patients were classified inyellow, green, and red areas Thanks to this triage coding, optimization ofthe diagnosis and treatment process of the patients is ensured..$^{[2,14]}$ In the study of Çevik et al. performed in a state hospital, in terms of priority status (triage) of emergency applications; the authors stated that the patients had Stable Conditions (24.34\%: green area), Serious Conditions (75.20\%: yellow area) and Emergencies requiring Urgent Interventions (0.47\%: red area). In addition, when patients who did and did not require emergency medical or surgical intervention werecompared according to their diagnoses; they stated that ENT and eyerelated disorders in non-urgent patients, and disorders related to the musculoskeletal system in emergencies were significantly higher, indicating that emergency services were used unnecessarily uınder these circumstances. ${ }^{[7]}$

In the study conducted by Köse et al. ${ }^{[3]}$ in a state hospital, $88.4 \%$ of the patients were discharged from the emergency service on an ambulatory basis, and when the rates of hospitalization, referrals, deaths and outpatient discharges were examined, and theinappropriate applications wereat a higher rate. According to these authors the most important reasons for inappropriately higher admission rates to the ERs includethe socioeconomic and cultural status of the region as well as the low level of education, being able to receive treatment immediately in the ERs without paying contribution fees forexaminations and medicationsreceived, and not benefiting from primary health care centers.

In the study conducted by Türkdoğan et al. ${ }^{[10]}$ in a state hospital, only $5.5 \%$ of the study patients were inthe Red Triage category, while $41.4 \%$ of them receivedthe Green Triage code. In addition, 95.9\% of the patients were discharged after diagnosis and treatment made in the emergency department.

In the study conducted by Kılıçaslanet al. in a university hospital, $10.42 \%$ of the patients who applied to the emergency department were in the very urgent patient group called Triage 1, 42.34\% were in the Triage 2 (Emergency) group, and nearly half of the patients (47.24\%) were in the ' non-emergency' group called Triage 3.

In the study conducted by Edirne et al. ${ }^{[9]}$ in a university hospital, $19.5 \%$ of the patients who applied to the Emergency Servicewere treated on an outpatient basis, and in this case, approximately one out of every five patients who applied to the emergency servicedid not meet the emergency patient criteria. In the study conducted by Tanrıkulu et al. ${ }^{[1]}$ in a training and research hospital, $94.8 \%$ of the patients were discharged on an outpatient basis after examination and treatment, and the authors also indicated higher rates of inappropriate use of emergency services. 
The ER of the private hospital where this study was conducted provides second-lineemergency care and the triage classification is made by trained nurses, emergency medical technicians. When we examine the patients according to triage coding and diseases, it is seen that more than half of the patients (56\%) who were admitted received the Green Triage Code. It has been determined that the vast majority (13.070)of the diseases in the Green Triage Code areas are upper respiratory tract infections (Table 3). In addition, $95.42 \%$ of the patients were found to be treated in the emergency service and discharged at similar ratesto the emergency service literature data of our country, which demonstrates that improper use of ERsis at a high rate. Whether it is a training and research hospital, a state hospital or a private hospital, unfortunately, patientsapply to the emergency service for social and cultural reasons and refrain fromwaiting in polyclinics, leaving their jobs during polyclinic working hours, and paying contribution fees.

In the study conducted by Kılıçaslan et al. ${ }^{[8]}$ the authors found that the most frequentlyapplications were madeon Monday (15.68\%), and the least number of applications occurred on Wednesday (13.53\%). When they examined the application hours, they stated that the most applications were made between 07:00 PM and 11:00 PM during night shift, then between 11:00, and12:00 AM during the day shift, and the least number of applications were made between 6:00 and 7:00 AM in the morning. They found that while the number of admissions decreased gradually, especially after midnight, a significant decrease was detected between 01:00 AM and 07:00 AM and patients applying after 02:00 AM were in the very urgent category.

In the study conducted by Türkdoğan et al. ${ }^{[10]}$ the authors found that the most frequently applications to the emergency department were made on Monday and the least on Thursday, and that applications increased in September, November, December and January, and decreased in April, May and June.

In the study conducted by Tanrikulu et al. ${ }^{[1]}$ the researchersstated that the patient admissionrates were 45.1\% between 08:00 AM and 05:00 PM, and 44.9\% between 05:00 PM and midnight, and the least number of admissions were madebetween midnightand 08:00 AM (10\%). They also found that the highest number of applications were madein December, while the minimum number of applications in April, while the number of applications increased as the winter season approached, and decreased in the summer months.

Patients mostly applyto the Private Hospital Emergency Service where this study was conducted in December (12\%) followed by January (11\%) and August (11\%). The least number of admissions were seen in July, with a rate of $6 \%$ (Figure 1). The patients appliedmostly on Sunday (25\%) followed by Saturday (19\%). It was determined that the least number of admissions were made in the middle of the week (Wednesday and Thursday with 10\% each) (Figure 2). When the timeof admissions wasevaluated, it was seen that the highest number of applications (30\%) were made in the working shift hoursbetween 08:00 PM and midnight which is called the prime time.

The least number of applications (7\%) were made from 04:00 AM to the start of working hours (Figure 3). The data of this study are compatible with the data of our country. It is seen that patient applications are increasing in and towards the winter months. We think that this is due to the fact that the people of the region, who went to their hometowns or holiday destinations in the summer, return towards the winter months, and also the epidemic of viral diseases with the cooling of the weather, and the increase in trauma due to rainfall. When the days of the week were examined, the highest number of applications occurred on Sunday followed by Saturdaywhen the polyclinics are closed after noon, because the staff works part time in private hospitals. When the hours of admission are examined, we see that the most applicationsweremade between 08:00 PM and 01:00 AMwhich iscalled the "prime time", in accordance with other studies in our country. We think that this is due to the fact that the local people working during the daytime come to the hospital during their rest periods.

\section{CONCLUSION}

The greater number of non-urgent patients in private hospital emergency services as well as in universities, training and research hospitals and state hospitals in our country shows that the problem of inappropriate use of emergency services in our country is increasing in all kinds of hospital emergency services. It is obvious that admission demographic data of the patients applied toemergency services is related to the socio-economic and cultural structure of the people in the region, therefore, emergency room managers and planners should try to get to know and evaluate the local community better.

In the winter months when the patient density is high, it is seen that additional physicians, health personnel, equipment are required at the weekend and between 8:00PM and 12:00 PM. It is necessary to make adjustments to increasethe staff working shifts duringprime-time hours and days when the greater number of patients apply, and to decrease the number of shiftsfrom 00:00 to $08 \mathrm{AM}$ when patient admissions are at the lowest level. With a good staff, physical structure and equipment plan, satisfaction ofboth patient/patient relatives and staff will be provided.

Limitations: Our study is based on limited databecause our study is single-centered and study population is livingin the suburbs of ametropolitan city of our country. We believe that it would be appropriate conduct a study with wider participation of people withdifferent social classes and in different socio-economic regions. 


\section{ETHICAL DECLARATIONS}

Ethics Committee Approval: Ethics committee approval vas taken from the Clinical Research Ethic Committee of Sultangazi Haseki Research and Education Hospital.

Informed Consent: All patients signed the free and informed consent form.

Referee Evaluation Process: Externally peer-reviewed.

Conflict of Interest Statement: The authors have no conflicts of interest to declare.

Financial Disclosure: The authors declared that this study has received no financial support.

Author Contributions: All of the authors declare that they have all participated in the design, execution, and analysis of the paper, and that they have approved the final version.

\section{REFERENCES}

1. Tanrıkulu C, Tanrıkulu Y, Karaman S. Acil Servis Başvurularının ve Acil Servisten Yatırılan Hastaların Gözden Geçirilmesi: Bir Eğitim Hastanesinin Kesitsel Analizi. J Clin Anal Med. 2014;5(2):130-4.

2. Aydın T, Aydın ŞA, Köksal Ö, Özdemir F, Kulaç S, Bulut M. Uludağ Üniversitesi Tıp Fakültesi Hastanesi Acil Servisine Başvuran Hastaların Özelliklerinin ve Acil Servis Çalışmalarının Değerlendirilmesi. Akademik Acil Tıp Derg. 2010;9(4):163-8.

3. Ataman Köse BK, M Reşit Öncü, Fuzili Tuğrul. Bir Devlet Hastanesi Acil Servisine Başvuran Hastaların Profili ve Başvurunun Uygunluğu. Gaziantep Medical Journal. 2011;17(2):57-62.

4. Akman Dömbekci H, Yılmaz FÖ, Özata M. Özel Hastane İşletmeciliğinin Mevcut Durumu ve Geleceği: Konya Örneği. Hacettepe Sağlık İdaresi Derg. 201821(4):675-97.

5. Yataklı Sağlık Tesislerinde Acil Servis Hizmetlerinin Uygulama Usul ve Esasları Hakkındaki Tebliğ. T.C. Sağlık Bakanlığı. Ankara. 2009. URL: https:// www.resmigazete.gov.tr/eskiler/2009/10/20091016-16.htm

6. Bol O, Altuntaş M, Kaynak MF, Koyuncu S, Biçer M, Öner G, et al. Uzun Süreli Tatillerin Acil Servis İşleyişine Etkisi. Journal of Anatolian Medical Research. 2019;4(1):13-10.

7. Çevik C, Tekir Ö. Acil Servis Başvurularının Tanı Kodları, Triyaj ve SosyoDemografik Açıdan Değerlendirilmesi. Balıkesir Sağlık Bilimleri Derg. 2014;3(2):102-7.

8. Kılıçaslan I, Bozan H, Oktay C, Göksu E. Türkiye'de Acil Servise Başvuran Hastaların Demografik Özellikleri. Türkiye Acil Tıp Derg. 2005;5(1):5-13.

9. Edirne T, Edirne Y, Atmaca B, Keskin S. Yüzüncü Yıl Üniversitesi Tıp Fakültesi Acil Servis Hastalarının Özellikleri. Van Tıp Derg. 2008;15(4):107-11.

10. Türkdoğan KA, Kapcı M, Akpınar O, Duman A, Bacakoğlu G, Türkdoğan FT, et al. Bir Devlet Hastanesi Acil Servisi Demografik Özellikleri: 2011 Yılı Meta Analizi. Journal of Clinical and Experimental Investigations. 2013;4(3):274-8.

11. Polat S, Özyazıcıoğlu N, Tüfekci F, Yazar F. Çocuk Acil Kliniğine Başvuran 0-18 Yaş Grubu Olguların İncelenmesi. Anadolu Hemşirelik ve Sağlık Bilimleri Dergisi. 2005;8(2):55-8.

12. Çavmak Ş, Çavmak D. Türkiye'de Sağlık Hizmetlerinin Tarihsel Gelişimi ve Sağlıkta Dönüşüm Programı. Sağlık Yönetimi Derg. 2017;1(1):48-10.

13. Gültaç A, Balçık PY. Suriyeli Sığınmacılara Yönelik Sağlık Politikaları. Sakarya Tıp Derg. 2018;8(2):193-12.

14. Akyolcu N. Acil Birimlerde Triyaj. Florence Nightingale Hemşirelik Derg. 2007;15(58):7-11. 